\title{
VJESNIKOVA NOVINSKA DOKUMENTACIJA U HRVATSKOM DRŽAVNOM ARHIVU KAO IZVOR ZA ISTRAŽIVANJE POVIJESTI ISTRE
}

\author{
Vlatka LEMIĆ \\ Hrvatski državni arhiv \\ Zagreb, Marulićev trg 21 \\ vlemic@arhiv.hr
}

\author{
UDK 022.43:655.3.066.12>(497.571)(091) \\ Stručni rad \\ DOI https://doi.org/10.31726/via.25.2
}

\begin{abstract}
Vjesnikova novinska dokumentacija, tj. Hemeroteka, koja se u Hrvatskom državnom arhivu nalazi od 2013. godine, sastoji se od isječaka članaka iz novina, tjednika i časopisa objavljivanih u tiskovinama s područja Jugoslavije i Hrvatske u razdoblju 1962. - 2006. Ova Zbirka nastala u Vjesniku sadrži oko $580 \mathrm{~d} / \mathrm{m}$ gradiva i desetljećima predstavlja jedinstveni informacijski izvor novinarima, medijskoj industriji te brojnim stručnjacima i znanstvenicima, a ujedno je i izvorno svjedočanstvo društva i vremena koje dokumentira.

U radu se na primjeru Istre opisuju mogućnosti istraživanja ove dokumentacijske cjeline i načini njezina korištenja.
\end{abstract}

Ključne riječi: Vjesnikova novinska dokumentacija, Hemeroteka, Istra

Keywords: Vjesnik Newspaper Documentation, newspaper and periodicals library, Istria

Parole chiave: Documentazione giornalistica del Vjesnik, Emeroteca, Istria

\section{Uvod - Vjesnikova novinska dokumentacija}

Prema Hrvatskoj enciklopediji, riječ Hemeroteka ima dva značenja i odnosi se na:

- »zbirku novina i časopisa i/ili

- zbirku izrezaka iz tekućih novina, časopisa ili koje druge tiskane građe, o određenim, unaprijed utvrđenim temama ili predmetima, obično složenu prema abecednom ili kronološkom slijedu natuknica, koje se koriste u informacijskim ustanovama kao brz izvor informacija i za dopunu podataka, osobito o aktualnim temama i događajima..1 ${ }^{1}$

Vjesnikova novinska dokumentacija, za koju se uvriježio naziv »Hemeroteka«, a često je u medijima nazivaju i »novinarski arhiv« ili »VND«, predstavlja jedinstvenu zbirku

»Hemeroteka«, u: Hrvatska enciklopedija, sv. 4 (Fr - Ht), Leksikografski zavod »Miroslav Krleža«, Zagreb, 2002., str. 515 (http://www.enciklopedija.hr/natuknica.aspx?id=24926). 
novinskih isječaka iz tiskovina koje su izlazile na području Jugoslavije i Hrvatske, a koje su više od pola stoljeća prikupljale i obrađivale dokumentacijske službe Novinsko izdavačke i štamparske kuće Vjesnik. Prema svjedočanstvima novinara koji su pratili njezin životni put: »Novinska dokumentacija osnovana je 1964. za potrebe svih tadašnjih izdanja NIŠPRO-a Vjesnik, odnosno svih medija u Hrvatskoj. U dokumentaciju su pri osnutku uvršteni i arhivi ratnih i predratnih redakcija, uglavnom kao zbirke kompleta: Novosti, (tadašnjeg) Jutarnjeg lista, Hrvatskog naroda i drugih.«²

O Vjesniku - izdavačkom poduzeću, »novinarskom arhivu« i ponajviše listu Vjesnik u posljednjih su desetak godina pisali brojni novinari u različitim medijima, uglavnom iz perspektive gašenja lista i stečaja poduzeća, a pojedina su opsežna istraživanja objavljena i u knjigama. ${ }^{3}$ Raspon tema kojima se ti radovi bave kreće se od uređivačke politike lista, razgovora s novinarima koji su radili u Vjesniku, pokušajima revitalizacije Vjesnika, stečaja i privatizacije do intervjua s protagonistima tih događanja i njihove kontekstualizacije unutar političke, gospodarske, kulturne i druge perspektive. Dosta se informacija ponavlja u različitim autorskim člancima, a neki se podatci različito interpretiraju, ovisno o stavovima autora, urednika i protagonista pojedinih napisa te su stoga za potrebe ovoga rada izdvojene samo činjenice koje se odnose na Vjesnikovu novinsku dokumentaciju. S obzirom da su odluke o njezinoj sudbini donosila nadležna tijela državne uprave, stručne postupke arhiva u odnosu prema ovom gradivu (kategorizacija Vjesnika, stručna mišljenja i rješenja, preuzimanja i dr.) također treba sagledavati u tom kontekstu. ${ }^{4}$

Iz pisanja Vjesnikovih kroničara može se saznati da je »do 2007. godine Vjesnikova novinska dokumentacija djelovala kao jedina javna novinska dokumentacija u Hrvatskoj, i njome su se, s obzirom na to da je dotad bila javna, osim novinara koristili i svi ostali kojima je trebala (primjerice obrazovne ustanove, u nastavne svrhe besplatno).$^{5}$

Iz brojnih je novinskih napisa o Vjesniku također poznato da je u pretvorbenim i tranzicijskim procesima nakon 1991. godine Vjesnikova dokumentacija pripala poduzeću Vjesnik d.d. gdje je 1999. zajedno s listom Vjesnik ušla u sustav Tiskare, koja je funkcionirala na tržišnim principima. U Vjesniku d.d. 2004. započela je i digitalizacija Vjesnikove novinske dokumentacije koja se zbog njezina opsega pokazala zahtjevnom i skupom, a kako ju Uprava Vjesnika d.d. nije imala poslovnoga interesa dalje održavati, 2006. godine, zajedno s drugim poslovnim kombinacijama, javno je objavila i poziv za njezino preuzimanje. ${ }^{6}$

Odlukom Sabora iz 2006. godine Vjesnikovu je novinsku dokumentaciju, zajedno s 14 dokumentalista, preuzela Hrvatska izvještajna novinska agencija (HINA), gdje je nastav-

Ivica GRČAR, »Vjesnik daruje novinsku dokumentaciju Državnom arhivu«, Lider (6. veljače 2006.). Dostupno na: https://lider.media/arhiva/1297/.

3 Vidi: Miroslav Edvin HABEK, Pad kuće Vjesnik. Zagreb, Zagreb, 2015.

4 Vidi, primjerice: Saša PAPARELLA, »Vjesnik novina koja je nestajala«, HND (14. travnja 2017.). Dostupno na: http://www.hnd.hr/vjesnik-novina-koja-je-nestajala.

$5 \quad$ ISTI, »Otvorite i “novinarski arhiv” (bivšu VND)«, Autograf.hr (4. travnja 2017.). Dostupno na: http:// www.autograf.hr/otvorite-i-novinarski-arhiv-bivsu-vnd/.

6 ISTI, »Vjesnik daruje novinsku dokumentaciju...«. Dostupno na: https://lider.media/arhiva/1297. 
ljena njena digitalizacija ${ }^{7} \mathrm{u}$ okviru projekta VND online. ${ }^{8}$ Na poticaj Ministarstva kulture RH Vjesnikova je novinska dokumentacija s drugim gradivom HINA-e 2013. proglašena kulturnim dobrom i upisana je u Registar kulturnih dobara RH. ${ }^{9}$

Sredinom 2013. Vjesnikova novinska dokumentacija, njoj pripadajuća kartoteka, uvezani kompleti novina i časopisa te zbirka knjižnične građe nekadašnje izdavačke kuće Vjesnik, kojima je HINA bila imatelj, zajedno sa šest djelatnika koji su radili na posebnom projektu digitalizacije i dokumentalističke obrade ove zbirke, preuzeti su u Hrvatski državni arhiv (HDA). Količina preuzetoga gradiva procijenjena je na oko 6609 registratora u konvencionalnom obliku, od kojih je petstotinjak digitalizirano.

Dolaskom u Arhiv ovo je gradivo, kao i druge dokumentacijske cjeline u fondovima i zbirkama HDA, opisano i koristi se u skladu s propisima o korištenju arhivskoga gradiva, no s obzirom na brojna otvorena pitanja u svezi s poslovanjem i stečajem Vjesnika i njegovih tvrtki sljednica, kao i velik javni interes za digitalizacijom i otvorenim pristupom ovoj dokumentacijskoj zbirci, često se u medijima piše o njoj i propitkuje njezina sudbina, pa i samo pitanje njezina smještaja.

\section{Fond Vjesnika u HDA}

Zbirku pod nazivom »Vjesnikova novinska dokumentacija« HDA je po službenoj dužnosti preuzeo u lipnju 2013. od HINA-e. Kako je osim ovoga gradiva HDA planirao preuzeti i druge cjeline gradiva Novinske izdavačke kuće Vjesnik, u prvom redu Zbirku fotografija lista Vjesnik i Vjesnikovu bazu podataka, tj. digitalizirane sadržaje, u Arhivu je formiran novi fond »HR-HDA-2031 Vjesnik« u kojem bi se objedinilo preuzeto gradivo i buduće akvizicije ovoga stvaratelja.

S obzirom da arhivsko gradivo u svezi s poslovanjem i radom Novinske izdavačke kuće Vjesnik koja je djelovala u razdoblju od 1945. do 2012. još nije preuzeto u Arhiv, a nakon Vjesnikova stečaja 2012. godine i drugih s time povezanih događanja koja su utjecala na sudbinu gradiva, njegovo stanje ni status nije moguće ni utvrditi. Fond trenutno čini cjelina Dokumentacijske zbirke koja se sastoji od triju serija: novinske dokumentacije, fotodokumentacije i baze podataka. Seriju fotodokumentacije čini gradivo »Fototeke redakcije lista Vjesnik« koju je HDA preuzeo od tvrtke Narodne novine - Press d.o.o. 2012. godine, nesređeno i dijelom mehanički oštećeno, u procijenjenoj količini od 500000 fotografija izvorno raspoređenih u 32 metalna ormara s ukupno 128 ladica, 145 registratora

7 Adrijana PITEŠA, »Kronologija slučaja: Vjesnikova arhiva. Kako je stvarana i zamalo uništena grandiozna zbirka novinskih članaka i fotografija«, Jutarnji list (8. lipnja 2013.). Dostupno na: https://www. jutarnji.hr/vijesti/vjesnikova-arhiva-kako-je-stvarana-i-zamalo-unistena-grandiozna-zbirka-novinskihclanaka-i-fotografija/1151672/.

8 Vidi: Željko HODONJ - Lana ŽAJA, »Mediji i demokracija, baza podataka, dubinsko pretraživanje, izravni pristup - digitalizacija novinskog arhiva i organizacija znanja u bazu podataka«, u: Sanja SELJAN - Hrvoje STANČIĆ (ur.), INFuture2007 Digital Information and Heritage, Odsjek za informacijske znanosti, Filozofski fakultet, Zagreb, 2007., str. 227-242.

9 Rješenje o utvrđivanju svojstva kulturnog dobra od 22. travnja 2013. (KLASA: UP/I-612-06/13-27/03, URBROJ: 565-08/3-13-1). 
i 24 kartonske kutije. ${ }^{10}$ Vjesnikova webna arhiva u PDF-u nastala 1998., kao i tekstovi i fotografije koji se na istom serveru čuvaju od 1996. godine, također su preuzeti u Arhiv.

Serija novinske dokumentacije ili »Hemeroteka« sastoji se od isječaka članaka iz novina, tjednika i časopisa objavljivanih u tiskovinama na području Jugoslavije i Hrvatske u razdoblju od 1962. do 2006. koje su prikupljale posebne službe Novinske izdavačke i štamparske kuće Vjesnik i sadrži oko 580 d/m gradiva složenih u 6105 registratora i 26 ladica (kartoteka). ${ }^{11}$

Zbirka je nastala i osnovno je sređena u Vjesniku. Sustavno prikupljanje isječaka započelo je u ranim 60-im godinama 20. stoljeća, a raspoređivani su u 15 osnovnih tematskih cjelina, odnosno područja znanja, unutar kojih su dalje formirane veće ili manje tematske podcjeline u kojima su isječci odloženi uglavnom prema kronološkom redoslijedu. Na većini je isječaka otisnut datum objavljivanja i naziv novina te su olovkom napisane oznake (npr. UP, DRUM, F i dr.).

Struktura Hemeroteke zadržala je izvorni poredak, tj. gradivo je popisano i složeno prema tematskim cjelinama s pripadajućim oznakama:

- JAVNE OSOBE: SVIH PODRUČJA (do 2003.) / SVE (od 2003.) / SPORT / RELIGIJA / PREDSJEDNICI - OS

- UNUTARNJA POLITIKA - UP

- HRVATSKA VANJSKA POLITIKA / SVIJET / MEĐUNARODNI ODNOSI:

- HRVATSKA VANJSKA POLITIKA (I JUGOSLAVIJA) - HRV

- SVIJET/MEĐUNARODNI ODNOSI - MO

- DRUŠTVO / ZDRAVSTVO / SOCIJALNA SKRB - DZS

- SUDSTVO / KRIMINAL - SUD

- KULTURA / UMJETNOST - KUL

- ODGOJ / OBRAZOVANJE - OBR

- SPORT - SP

- ZNANOST - ZNA

- RELIGIJA - REL

- KOMUNIKACIJE / MEDIJI - KOM

- PROMET - PROM

- EKOLOGIJA - EKO

- EKONOMIJA / GOSPODARSTVO / FINANCIJE - EGF

10 O sređivanju su Vjesnikove Fotodokumentacije 29. siječnja 2014. djelatnici Fotolaboratija HDA u Arhivu održali stručno izlaganje u sklopu Arhivske info srijede.

11 Vjesnikova novinska dokumentacija 1964-2006, Popis. Zagreb. Hrvatski državni arhiv, 2013., str. 2. Ovo obavijesno pomagalo od 242 stranice dostupno je na: http://arhinet.arhiv.hr/_Pages/PdfFile. aspx?Id=3091. 
Prilikom primopredaje gradiva u Arhiv $\gg$ Tehnički popis VND gradiva« koji je izradila HINA 2006. (za projekt digitalizacije) promijenjen je na način da su iz izvornika zadržani nazivi i opis sadržaja (polja) te dodane nove oznake tehničkih jedinica (registratora) koje se sastoje od oznake/slovčane kratice područja i tekućega rednog broja registratora unutar svakoga područja.

Kako je Hemeroteka arhivistički nesređena, taj popis preuzetoga gradiva koji je nastao na temelju popisa izrađenih u Vjesniku, služi kao obavijesno pomagalo za korištenje gradiva, tj. gradivo se naručuje za korištenje prema oznaci tehničkih jedinica (KUL-1) iz Popisa.

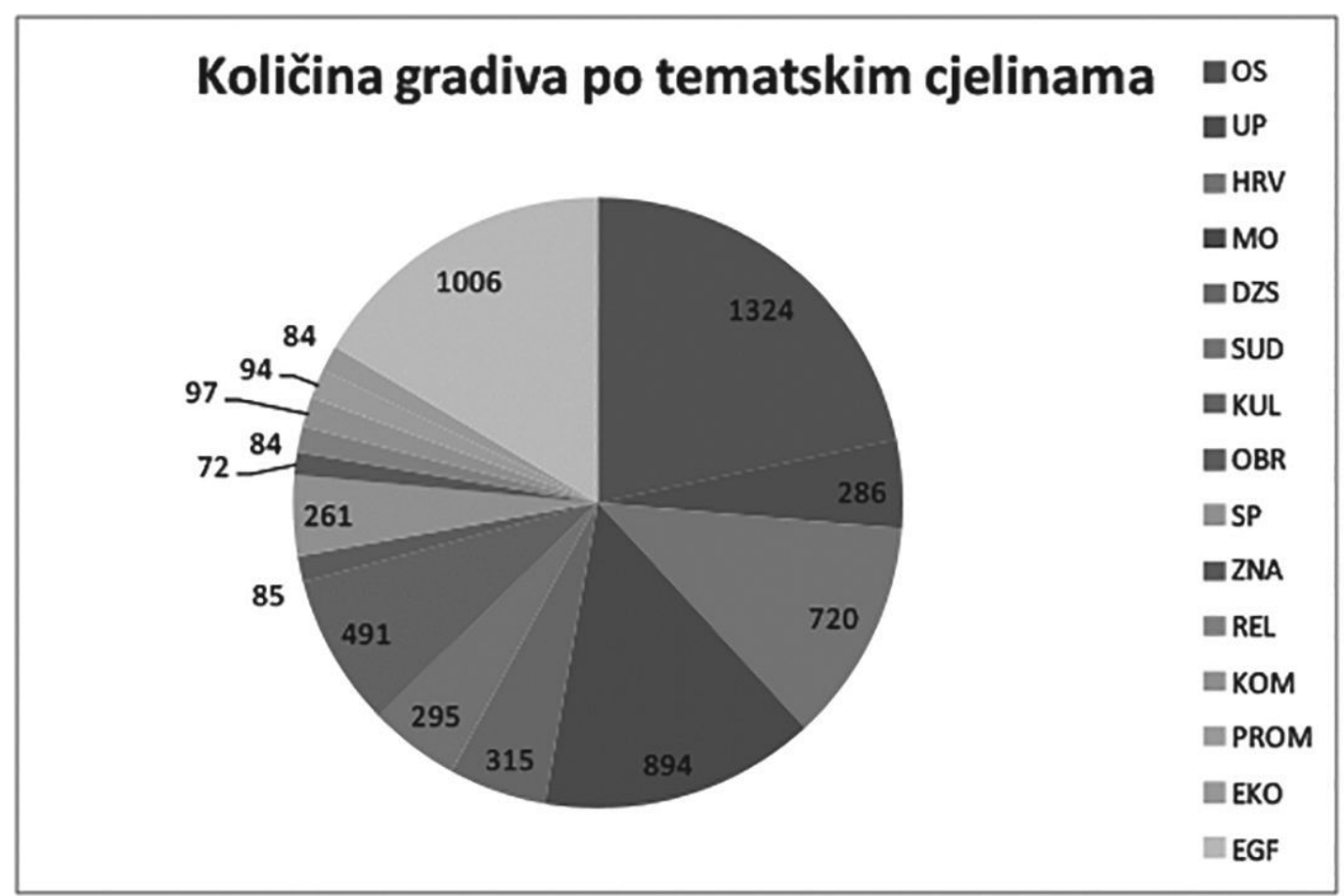

Slika 1. Prikaz količine gradiva u pojedinim tematskim cjelinama

\section{Tema Istra - primjer istraživanja}

Na primjeru Istre prikazana je mogućnost istraživanja prema postojećem Popisu gradiva koji je strukturiran na opisani način. Tražeći pojam Istra u popisu od 6105 registratora pronađeno je 12 registratora u kojima se u nazivu podcjeline ili opisu sadržaja spominje riječ Istra, prema sljedećim područjima: 
- Unutarnja politika (4)

\begin{tabular}{|l|l|l|l|}
\hline \multicolumn{2}{|l|}{$\begin{array}{l}\text { Oznaka i broj } \\
\text { registratora }\end{array}$} & Naziv podcjeline & Sadržaj registratora \\
\hline UP & 26 & HRVATSKA & $\begin{array}{l}\text { ilirski pokret, Poljička Republika, povijest } \\
\text { hrvatske državnosti, povijest Istre, urota zrin- } \\
\text { sko-frankopanska, Vojna krajina, Zlatna bula }\end{array}$ \\
\hline UP & 167 & ŽUPANIJE & $\begin{array}{l}\text { općenito, pojedinačno osim Zagrebačke, Pri- } \\
\text { morsko-goranske i Istarske županije, župani }\end{array}$ \\
\hline UP & 168 & ISTRA & $\begin{array}{l}\text { dvojezičnost, Prvi kongres Istrijana, Statut } \\
\text { Istarske županije, vidi regionalizacija }\end{array}$ \\
\hline UP & 236 & RAT U HRVATSKOJ & $\begin{array}{l}\text { Gorski kotar, mjesta, Gospić, Gračac, Istra, } \\
\text { Lika, Obrovac, Otočac, područja zahvaćena } \\
\text { ratom, Rijeka, Pula, Vrsar }\end{array}$ \\
\hline
\end{tabular}

- Hrvatska vanjska politika / Svijet / Međunarodni odnosi (2)

\begin{tabular}{|l|l|l|l|}
\hline \multicolumn{2}{|l|}{$\begin{array}{l}\text { Oznaka i broj } \\
\text { registratora }\end{array}$} & Naziv podcjeline & Sadržaj registratora \\
\hline HRV & 384 & ISTRA & Hum \\
\hline HRV & 394 & RIJEKA & $\begin{array}{l}\text { ISTRA, privreda Rijeke, urbanizam / stano- } \\
\text { gradnja Rijeke, ZAJEDNICA OPĆINA RIJEKA }\end{array}$ \\
\hline
\end{tabular}

- Promet (2)

\begin{tabular}{|c|c|c|c|}
\hline \multicolumn{2}{|c|}{$\begin{array}{l}\text { Oznaka i broj } \\
\text { registratora }\end{array}$} & \multirow{2}{*}{\begin{tabular}{|l|} 
Naziv podcjeline \\
PROMET \\
\end{tabular}} & \multirow{2}{*}{\begin{tabular}{|l|} 
Sadržaj registratora \\
$\begin{array}{l}\text { Astaldi } \rightarrow \text { Zagreb - Goričan, Bechtel } \rightarrow \text { Zagreb } \\
- \text { Split, Bina Istra }\end{array}$ \\
\end{tabular}} \\
\hline PROM & 1 & & \\
\hline PROM & 20 & HRVATSKA & $\begin{array}{l}\text { autoceste, ceste u gradovima SRH, ceste u regi- } \\
\text { jama SRH, Gorski kotar, Lika, Istra, Dalmacija, } \\
\text { Jadranska orijentacija: Karlovac - Rijeka, Karlo- } \\
\text { vac - Plitvice, Podravska magistrala, PROMET } \\
\text { U SRH, Zagorska magistrala, Zagreb - Rijeka, } \\
\text { Zagreb - Rijeka - Trst, Zagreb - Karlovac, Za- } \\
\text { greb - Šentilj, Žumberačka magistrala }\end{array}$ \\
\hline
\end{tabular}

- Ekonomija / Gospodarstvo / Financije (4)

\begin{tabular}{|l|l|l|l|}
\hline $\begin{array}{l}\text { Oznaka i broj } \\
\text { registratora }\end{array}$ & Naziv podcjeline & Sadržaj registratora \\
\hline EGF & 252 & HRVATSKA & $\begin{array}{l}\text { crna metalurgija, Istra, Kumrovec, miniželjeza- } \\
\text { re, RUDARSTVO I METALURGIJA, željezara } \\
\text { Sisak, željezara Split, željezare }\end{array}$ \\
\hline
\end{tabular}


V. LEMIĆ, Vjesnikova novinska dokumentacija u Hrvatskom državnom arhivu... / VIA svezak 25

\begin{tabular}{|l|l|l|l|}
\hline EGF & 357 & REPUBLIKA HRVATSKA & $\begin{array}{l}\text { cementare, Dalmacijacement d.d. Split, INDU- } \\
\text { STRIJA CEMENTA, Istra cement internatio- } \\
\text { nal, Pula (Giulio Revelante), Koromačno d.d., } \\
\text { Našicecement, Našice, Sloboda, Podsused }\end{array}$ \\
\hline EGF & 724 & POLJOPRIVREDA & $\begin{array}{l}\text { donacija ovaca iz Australije, genetski centar } \\
\text { Istra, kozarstvo, nomadsko stočarstvo, ov- } \\
\text { čarstvo, STOČARSTVO, svinjogojstvo, uzgoj } \\
\text { činčila, uzgoj glista, uzgoj kunića, uzgoj nojeva, } \\
\text { uzgoj nutrija, uzgoj puževa, uzgoj svilene bube }\end{array}$ \\
\hline EGF & 862 & $\begin{array}{l}\text { TURIZAM I UGOSTITELJ- } \\
\text { STVO }\end{array}$ & $\begin{array}{l}\text { Červar, Duga uvala, ISTRA, Novigrad, obala, } \\
\text { Piran, Poreč, Portorož, Pula, Rabac, Rovinj, } \\
\text { SLOVENIJA, Umag }\end{array}$ \\
\hline
\end{tabular}

Uvidom u svaki od pojedinih registratora pregledane su i opisane cjeline gradiva u kojima se spominje Istra te djelomice popisani prikupljeni novinski isječci kako bi se ilustrirao način njihova prikupljanja.

\section{Istra u temi Unutarnja politika}

Tako je u registratoru s oznakom UP-26 ispod naslova Povijest Hrvatske, na hrptu dalje navedeno: Povijest hrvatske državnosti - Ilirski pokret, Vojna Krajina, Povijest Istre, Poljička republika, Urota Zrinsko-Frankopanska, Zlatna Bula. Isječci u ovom registratoru složeni su u pedesetak tematskih cjelina, uloženih u zasebne košuljice s rukom ispisanim nazivima koji pokrivaju širok raspon tema, od općih, poput Hrvatske povijesti, Hrvatska povijest - zemljovidi, Povijest hrvatske državnosti, Hrvatski kraljevi i slično, do pojedinih pojava i događaja, kao što su Uskoci, Ilirski pokret, Rakovički ustanak, Sigetska bitka 1566. i dr.

U četvrtoj po redu košuljici, pod nazivom Povijest Hrvatske, u prvom fasciklu, Povijest; Seljačka buna, Istra, Zlatna Bula, kao druga cjelina nalazi se podlistak Težnje, borbe, porazi, uspjesi - Sjedinjenje Istre s maticom Hrvatskom dr. Petra Strčića. Kao što naziv kaže, radi se o seriji od 35 feljtona koje je napisao dr. Petar Strčić, povjesničar, a izlazili su dnevno u Novom listu od 25. rujna do 29. listopada 1993. Podlistak nosi naziv: Istra, Rijeka, Otok Cres, Otok Lošinj, Zadar 1943. godine. Napisani su povodom 50. obljetnice sjedinjenja s maticom-domovinom Hrvatskom, a sačuvana su 22 nastavka.

Iduća, treća cjelina, pod nazivom Istra »Sjećanja na egzodus Hrvata Istre od 1918 do 43.« sastoji se od sljedećih članaka:

- T. Jakovina: Eksodus Istarskih Hrvata (Povjesnica); Vjesnik, 4. studenoga 1997.

- S. Benić i M. Rimanić: Istra definitivno u Hrvatskoj i Hrvatska definitivno u Istri (Pazin: Skupom »Hrvatska Istra - sjedinjenje« u organizaciji Istarskog HDZ-a obilježena 54. obljetnica sjedinjenja Istre s Maticom domovinom); Novi list, 28. rujna 1997.

- R. Peter: Od vremena ricinusova ulja do hrvatske stvarnosti - Obilježavanje sjećanja na egzodus Hrvata Istre; Obzor, 25. listopada 1997. 
- Tomislav Klauški: Rasvijetljen dio istine o prešućivanoj tragediji: Znanstveni skup $»$ Talijanska uprava i egzodus Hrvata (1918. - 1943.)«; Novi list, 25. listopada 1997. u rubrici Novosti

- T. Klauški: Talijanski fašizam nije uspio skršiti hrvatski duh Istre - Međunarodni skup u Zagrebu (Tjedan posvećen egzodusu Istarskih Hrvata između dva rata); Novi list, 24. listopada 1997.

- T. Klauški: Sudbina Istrana sudbina je cjelokupnog hrvatskog puka (Zagreb: Otvoren tjedan »Sjećanja na egzodusu Hrvata Istre od 1918. do 1943.«); Novi list, 23. listopada 1997.

- D. Načinović: Iz prošlosti moramo naučiti izbjegavati zlo (Sa završnice zagrebačkog dijela programa Manifestacije »Sjećanja na egzodus Hrvata Istre«); Novi list, 27. listopada 1997.

- M. R.: Opomena da se više nikad ne vrate mračne sile prošlosti (Jučer u Ježenjskom brigu završena manifestacija »Sjećanja na egzodus Hrvata Istre za vrijeme talijanske uprave i okupacije 1918. - 1943.«); Novi list, 27. listopada 1997.

U sljedećoj cjelini, »125. obljetnica održavanja prvog tabora Hrvata Istre i Kvarnerskih otoka«, nalaze se članci:

- V. Spinčić: Kastav na raskrižjima prošlosti (Uz 125. obljetnicu I. tabora Hrvata Istre i Kvarnerskih otoka u Kastvu održan znanstveni skup); Novi list, 19. svibnja 1996.

- V. Spinčić: Drugi tabor na Sv. Mihovilu 21. svibnja 1911. (125. obljetnica I. tabora Hrvata Istre i Kvarnerskih otoka - 4); Novi list, 19. svibnja 1996.

- V. Spinčić: Jačanje lokalne samouprave jača Hrvatsku i demokraciju (Središnja proslava 125. obljetnice održavanja prvog tabora Hrvata Istre i Kvarnerskih otoka na Sv. Mihovilu kod Kastva); Novi list, 20. svibnja 1996.

U petoj po redu košuljici, pod nazivom »Hrvatska povijest - razno«, nije dodatno opisan sadržaj, no pregledom prikupljenih članaka koji govore o hrvatskoj državnosti, obljetnicama u svezi s povijesnim i političkim događajima i osobama te sličnim temama, može se naći i onih u svezi s Istrom, primjerice:

- M. Tomasović: Zablude i propusti o hrvatskoj povijesti i književnosti u najnovijoj talijanskoj povijesti (Sporno); Vjesnik, 12. ožujka 1997.

Pišući o krivotvorenju povijesnih činjenica $u$ »Enciklopediji Zanichelli«, na više mjesta govori i o povijesti Istre.

U jednoj od idućih košuljica, također naslovljenoj »Hrvatska povijest«, nalazi se članak:

- A. Černjul: Ni Jugoslavije, ni YU-zastave (Što se događalo na brodu »Viribus Unitis« u pulskoj luci 1918. godine); Večernji list, 15. ožujka 1993. pod nazivom »Večernji list istražuje kako je prešućivana povijest«, 
nastao na temelju intervjua s Jožom Pretnarom, kapetanom bojnoga broda u mirovini koji se bavi vojno-pomorskom i lokalnom poviješću.

U košuljici pod nazivom »Arena, Sudbine i događaji iz kovčega prošlosti« među jedanaest feljtona različitih autora, objavljenih u istoimenoj rubrici, nalazi se i članak:

- B. Perić: Svaka je obitelj postala školom (Roman patnje u crno zabrađene Istre, koju su nakon prvog svjetskog rata pretvorili u najstrašnije mučilište najprije D’Anunzzievi, pa zatim Mussolinijevi porobljivači (3)); 12. ožujka 1994.,

iz kojeg se može zaključiti da postoji još dijelova ovoga niza. Članci prikupljeni unutar ove teme - od prikaza brojnih publikacija, znanstvenih skupova, eseja do znanstvenih razmatranja - često pisani iz pera istaknutih historiografa značajna su informacija povjesničarima i drugim istraživačima o tome tko je, kada i o čemu pisao i kako je to bilo medijski popraćeno.

Registrator s oznakom UP-167 nosi naziv Hrvatske županije, s podnaslovima: Župani, Općenito, Pojedinačno i podijeljen je na više cjelina: Županije općenito i one posvećene svakoj od županija. U košuljici Županije općenito nalaze se članci posvećeni radu i organizaciji državne uprave i lokalne samouprave, županijskoj administraciji i uredima, pitanjima racionalizacije, sjednicama Kolegija hrvatskih župana koje su se održavale diljem Hrvatske, izborima župana i njihovu javnu djelovanju, županijskim granicama i drugim pitanjima, primjerice članak:

- D. Herceg: »Balvan« na Preluci (Županije i njihove granice); Vjesnik, 26. svibnja 1993.,

a bavi se pokretanjem inicijative u Opatiji, Lovranu i Matuljima za izdvajanjem iz Primorsko-goranske i priključenje Istarskoj županiji. U feljtonu od 10 nastavaka autora dr. Zorana Klarića, koji je izlazio u Večernjem listu od 3. do 13. kolovoza 1992. pod nazivom »Hrvatske županije (Kakve bi trebale biti)«, 7. i 8. nastavak bavi se Pazinskom županijom.

U ovoj se cjelini nalaze i članci posvećeni ustrojstvu županija, popisi gradova, općina i naselja, o Županijskom domu Hrvatskoga sabora i županijskim oznakama, složeni u više tematskih košuljica od po nekoliko članaka, primjerice u onoj pod nazivom »Simbolika obilježja hrv. županija - grbovi« nalaze se članci:

- P. Radošević, Medulin: O grbu i zastavi Istre - Koza najprilagodljivija i najkorisnija; Novi list, s.a.

- A. Latinović: Grb i zastava podijelili vijećnike (Sjednica Skupštine Županije istarske); Vjesnik, 16. srpnja 1994.

dok se u košuljici »Suradnja županija - posjet Skoplju« nalazi članak:

- D. Šantić: Odmrzavanje poslovne suradnje (Gospodarstvenici Primorsko-goranske i Istarske županije posjetili Skoplje); Novi list, 29. siječnja 1994. 
Registrator s oznakom UP-168 pod nazivom Istra u cijelosti se odnosi na istarske teme: Statut Istarske županije, Dvojezičnost, Prvi kongres Istrijana i dr. Prva košuljica, pod nazivom »Istra - Istarski projekti; IDS-SDP; 2003; 2004.« sadrži članke:

- M. Urošević; IDS: Ruši se referendumska kula od laži i podvala; Vjesnik, 13. srpnja 2003.

- M. Urošević: Što je dobro za Istru dobro je i za Hrvatsku (Kakva će biti budućnost istarskih veleprojekata; Vjesnik, 11. siječnja 2004.

- M. Urošević: Istarska predizborna simultanka; Vjesnik - Panorana, 5. srpnja 2003.

- M. R.: Politička klima u Istri blokira strana ulaganja (Damir Kajin i Dorotea Pešić Bukovac) o gospodarskim prilikama u Istri; Novi list, 22. kolovoza 2003.

- R. Frank. Bolković: Koalicija s IDS-om dugoročno će štetiti SDP-u u Istri (Politika i biznis); Novi list, 24. srpnja 2003.

- N. Šantić: Ništa novog na Učki; Novi list, 21. srpnja 2003.

- M. Urošević: Prvi dan prikupljeno 3000 od potrebnih 5000 potpisa (počelo potpisivanje peticije za referendum o istarskom zemljištu i »Brijunskoj rivijerik); Vjesnik, 6. srpnja 2003.

- M. Urošević: Delbianco referendumom protiv Jakovčića i »Brijunske rivijere«; Vjesnik, 15. lipnja 2003.

- M. Urošević: Izaberete i krenete u jednom od dvadeset smjerova (Istra dobila novi turistički vodič); Vjesnik, 1. lipnja 2003.

- M. Urošević: Istarski referendum - bumerang ili trambulin; Vjesnik, 10. kolovoza 2003.

- N. Božić: Tko će vladati Istrom; Jutarnji list, 29. srpnja 2003.

- N Jelovac: Talijanski Drang nach Osten (Reagiranja - Hoćemo li u Istri i Dalmaciji smjeti govoriti hrvatski); Slobodna Dalmacija, 2. srpnja 2003.

- N. Šantić: Kajin: Nema vlade lijevog centra bez podrške IDS-a (Koalicija SDP-a i IDS-a nikoga na političkoj sceni nije posebno iznenadila); Novi list, 4. srpnja 2003.

- M. Urošević: Je li zavičaj utočište pred globalizacijom; Vjesnik, 18. svibnja 2003.

- M. Jelovac: »Glas Istre« protiv IDS-a i obrnuto (Medijsko-politički sukob u Istri); Vjesnik, 29. srpnja 2003.

Druga košuljica, pod nazivom »Istra - Prvi svjetski kongres Istrijana 13-16. 4. 95«, sastoji se od više od stotinu članaka djelomice grupiranih zajedno, od kojih oni sadržajno vezani uz naziv na košuljici predstavlja tek manji dio. Tako se među prvima, negrupiranim člancima, nalaze i oni koji se tematski nastavljaju na prethodnu cjelinu, a i oni koji se bave drugim pitanjima, kao što su:

- M. Rakovac: O nestanku nesuđene euro-regije Istre (Zapadni prolaz); Vjesnik - Panorama, 29. ožujka 2003. 
- M. Rakovac: Istra, koja je pokazala da može vrlo mnogo: hrvatsko iskustvo i moguća formula za Europu; Vjesnik, 10. svibnja 2003.

- B. Žužić: Dvojezični duh Istre nitko neće pokoriti (Reakcije nakon odluke Ustavnog suda o ploči na županijskoj zgradi u Pazinu); Slobodna Dalmacija, 18. veljače 2003.

- V. Hammer: Zima u gradićima gornje Bujštine (Zapisi iz Istre); Vjesnik, 2. veljače 2003.

- T. Gromača: Koga Vodnjan nosi (Feralova reporterka otkriva Istru kakvu slabo poznajemo); Feral Tribune, 13. srpnja 2002.

- A. Knifer: Istarska enciklopedija: Prvo regionalno leksikografsko izdanje u Hrvatskoj; Globus, 27. prosinca 2002.

- D. Pilić: Istri kruh, Dalmaciji igre (Kako i zašto tri lava gledaju u leđa jednoj kozi); Slobodna Dalmacija, 11. svibnja 2002.

i brojni drugi.

Tematska cjelina »Istarska himna« sadrži tri članka dok iduća, pod nazivom »Istra 2001.«, okuplja više od četrdeset članaka, uključujući:

- V. Brnabić: Istrani će za razliku od ostalih Hrvata, u Sloveniju i Italiju po posebnom traku (Projekt »Istra-Kras-More« ili prvi korak prema Euroregiji); Večernji list, 11. kolovoza 2001.

- I. Đikić: Istra u Zagreb, Istra iz Zagreba (Novi stari nesporazumi između Zagreba i buntovničkog poluotoka); Feral Tribune, 9. lipnja 2001.

- I. Ušćumlić: Hum, Kotli i Grožnjan - mali raj u središtu Istre; Vjesnik, 30. siječnja 2000.

- T. Klauški: Navala stranaca na istarske kuće; Nacional, 31. srpnja 2001.

- D. Herljević: Grijeh je od Istre raditi slučaj (Iz Tuđmanovih crtića o Istri Zagreb nije ništa naučio); Novi list, 14. travnja 2001.

- N. Vlašić: Istra po mjeri Mediterana; Novi list, 11. travnja 2001.

- M. Urošević: Delbianco spreman za sporazum s Loredanom Štok; Vjesnik, 29. svibnja 2001.

- R. Frank: Unutrašnjost Istre i seoski turizam u raljama IDS-a; Novi list, 30. lipnja 2001.

- S. Fable: Odcjepljenje istarske malvazije; Jutarnji list, 16. kolovoza 2001. i dr., a u idućoj koja se zove »Povijest - egzodus Hrvata Istre« nalaze se članci:

- D. N.: Sjećanja na egzodus Istre (Danas u Zagrebu početak petodnevne manifestacije); Novi list, 22. listopada 1997.

- G. Novačić: Otvoren tjedan: Sjećanja na egzodus Hrvata Istre od 1918. do 1943.; Vjesnik, 23. listopada 1997. 
Slijede tematske cjeline Istarska županija - Deklaracija o multietničnoj i višejezičnoj Istri; Istra - Heraldika, Zastave, Pazin, Ostalo; Istra - Heraldika, Zastave; Istrorumunji; (Neo)fašistički plakati u Istri; Istra do 2000.; Istra 2002. i najopsežniji Istra - Prvi sv. kongres Istrijana koji sadrži nekoliko desetaka članaka koji se odnose na ovaj skup, pitanja regionalizama, deklaracije, odjeke i reagiranja i sl., primjerice:

- M. Urošević: Neprihvatljive obje deklaracije (Istarski liberali o kongresu Istrijana); Vjesnik, 19. travnja 1995.

- D. Đuretek: Zaboravili da su u Hrvatskoj (Nakon Prvog svjetskog kongresa Istrijana); Večernji list, 18. travnja 1995.

- M. Jajčinović: Nove dvojbe (Kongres Istrijana i istarske posebnosti); Večernji list, 24. travnja 1995.

- R. Peter: Uskrsnuće istrijanstva (Uoči Prvog svjetskog kongresa Istrijana); Slobodna Dalmacija, 14. travnja 1995.

- A. Latinović: Razborita riječ o Istri (Pred Svjetski kongres Istrana od 13. do 16. travnja u Puli); Vjesnik, 27. ožujka 1995.

- N. Klapčić: Iredentisti u HDZ-u (Iza kulisa Prvog svjetskog kongresa Istrijana); Arkzin, 20. travnja 1995. i brojni drugi.

Treća, najopsežnija košuljica u ovom registratoru, »Istra - "Zemlja Istra”, Talijančenje Istre«, sadrži više stotina članaka grupiranih u nekoliko tematskih cjelina: Istra 95.; Istra 94.; Dvojezičnost - Istra, IDS, Pazin, Ploča/zastava, Incidenti, Skidanje zastava; Istra - "Zemlja Istra"; Regionalizacija Istre, Ulazak Istarske županije u Skupštinu Europskih regija; Statut Istarske županije, Dvojezičnost, od kojih svaka sadrži desetke članaka o navedenim temama napisanih iz različitih perspektiva i stajališta.

U posljednjoj se košuljici u registratoru koja nosi naziv »Istarska županija - Statut županije, Skupština europskih regija« također nalazi više stotina članaka, grupiranih u četiri tematske cjeline: Statut Istarske županije, Istarska županija - grb, Županija XVIII Istarska, župan Delbianco i kao zanimljivost, jedan izdvojeni članak iz slovenskoga tiska:

- G. Moravček: Zamere Zagrebu zaradi neavtonomije regij; Delo, 30. travnja 1992.

Registrator s oznakom UP-236 nosi naziv Rat u Hrvatskoj, s dodatnim podnaslovima na hrptu: »Područja zahvaćena ratom; Istra; Gorski kotar i Lika« sastoji se od dviju košuljica - Lika i Istra, koja se dalje dijeli na tri tematski cjeline: Gorski kotar, Delnice, Srpske Moravice, Vrbovsko, Josipdol, Žuta Lokva; Istra - Rijeka i Istra - Pula. U košuljici pod nazivom Istra - Rijeka prikupljeni se članci odnose na granatiranje Rijeke, blokadu riječke luke, aktivnosti u Kriznom štabu Općine Rijeka, aktivnosti štabova civilne zaštite na području Rijeke i širega riječkog područja, odlazak JNA iz Rijeke i srodne teme, uz nekoliko članaka koji se odnose na Istru: 
- Z. Tarle: Istra se malčice izmakla (Rijeka i pulska regija); Borba, 19. rujna 1991.

- M. B. B.: Garda i u Puli (Istra se užurbano priprema za obranu od eventualne agresije); Večernji list, 17. rujna 1991.

- M. Urošević: Ponoćni rafali i blokirane vojarne; Vjesnik, 19. rujna 1991.

U košuljici pod nazivom »Istra - Pula« nalazi se pedesetak članaka o ratnom razdoblju na području Istre, primjerice:

- N. Unukić: Ubojita reklamacija (S hrvatskim roniocima u akciji vađenja granata i mina koje je okupator posijao u pulskom akvatoriju); Večernji list, 14. svibnja 1992.

- M. Urošević: Dogovor, a ne kapitulanstvo (Potpredsjednik Vlade dr. Zdravko Tomac u Puli); Vjesnik, 12. prosinca 1991.

- Redakcijski izvještaj: Bjesni pozadinski rat (Krajnje napeta politička situacija na jugu Istre); Večernji list, 1. studenoga 1991.

- D. Sponza: Vojni avioni samo s dozvolom Hrvatske (Stanje u Pulskoj općini); Glas Istre, 9. listopada 1991.

- D. Mijandrušić: S Barovićem otišao mir (Napeti mir / Koliko je Istra daleko od rata); Nedjeljna Dalmacija, 3. listopada 1991.

- D. S.: Paljba i dalje uznemiruje Pulu (Na jugu Istre još jedna nemirna noć i jutro); Novi list, 28. rujna 1991.

- D. Damjanović: Mupovci oterali gardiste (Pula nije više miran grad); Politika, 25. rujna 1991.

- M. Maršić: Ubojica gardista s Lošinja slobodno šeta Pulom; Slobodni tjednik, 21. studenoga 1991.

- M. Bedalov-Bugarin: Pustoš vrsarskog aerodroma; Večernji list, 23. prosinca 1991. i brojni drugi.

\section{Vjesnikova Hemeroteka kao povijesni izvor}

Hemeroteke i druge dokumentacijske zbirke, koje brojne ustanove vode sa svrhom dokumentiranja svojih aktivnosti, predstavljaju značajan izvor podataka za povijesni pregled djelovanja i rada pojedine institucije, a često i cijeloga područja neke djelatnosti, društvenih zbivanja i povijesnoga konteksta svojega nastanka. U tom je smislu Vjesnikova Hemeroteka jedinstven primjer po svome opsegu - sadrži ne samo izdanja nakladničke kuće Vjesnik koja ju je pokrenula i vodila nego i druga izdanja koja su izlazila na jednom određenom području u razdoblju od pedesetak godina. Novinska kuća Vjesnik bila je uspješno izdavačko poduzeće čije su tiskovine izlazile u velikim nakladama i okupljale istaknute autore, priznata i u europskom okruženju, što njezinoj dokumentacijskoj zbirci pruža stručnu relevantnost i značaj. O tome svjedoči i trajni interes struke za njezinim istraživanjem i otvaranjem javnosti, kao i isticanje Vjesnikove uloge u povijesti novinarstva u Hrvatskoj korištenjem Vjesnikovih izdanja u edukaciji mladih stručnjaka. 
Sama je struktura ove Hemeroteke - izbor tematskih cjelina i odrednica - svojevrsna slika i kronologija novinarske struke s obzirom da je od svoga nastanka prvenstveno podupirala novinarski istraživački rad, a sama je dokumentacija ujedno i svjedočanstvo o životu u Hrvatskoj i većini susjednih zemalja u drugoj polovici dvadesetoga stoljeća. Znatan je dio dokumentacije u svezi s lokalnim temama, osobama i značajnim događajima iz javnoga života pa može biti koristan ustanovama, organizacijama i pojedincima koji se njima bave.

Uvidom u pojedine tematske cjeline i sadržaje, razvidno je da popis pruža okvirnu sliku za istraživanje specifične teme te da je za cjelovito i potpuno istraživanje potrebno pregledati sva područja i tematske odrednice koje su posredno ili neposredno u svezi s primarnim predmetom istraživanja (primjerice, teme u svezi s Pulom mogu se nalaziti u temi Istra, ali isto tako i uz pojedine osobe, pojedinačna područja - gospodarstvo, turizam, kultura i dr.). Treba također uzeti u obzir i različitost novinskih vrsta (reportaže, intervjui, kolumne, komentari, feljtoni, izjave i dr.) te postojanje fotografija, ilustracija i drugih priloga što također mogu sadržavati vrijedne informacije, a do kojih istraživači mogu doći samo osobnim uvidom u dokumentaciju.

Pregledom novinskih isječaka unutar pojedinih tematskih cjelina, vidljiv je subjektivni pristup dokumentalista koji su ih predmetno obrađivali s obzirom na česta preklapanja i ponavljanja istih ključnih riječi i sadržajnih odrednica, međutim, to ne umanjuje njezinu informacijsku vrijednost. Mogućnosti novih tehnologija u organiziranju gradiva i podataka te pristupu informacijama prepoznate su kao velik potencijal ove zbirke kod svih njezinih dosadašnjih imatelja te je stoga u proteklih petnaestak godina bilo više pokušaja digitalizacije ovoga gradiva, što je, ovisno o financijskim, tehničkim i organizacijskim mogućnostima, ujedno i njezina budućnost.

Digitalizacijom i indeksiranjem Vjesnikove novinske $\mathrm{i}$ fotodokumentacije $\mathrm{u}$ relacijskim bazama podataka otvorile bi se neograničene mogućnosti opisa i pretraživanja podataka sadržanih u ovoj dokumentaciji (osobe, teme, institucije, zemljopisne odrednice, vremenske odrednice, izvori i dr.), a bilo bi moguće i stvaranje novih sadržaja, kao što su izložbe i tematske publikacije, edukativni i promotivni sadržaji, korištenje u programima manifestacija i u raznim drugim oblicima ponude kulturnih sadržaja. Digitalne zbirke novina, tiska i fotografija, dokumentacijske baze izdavačkih i medijskih kuća i slični interaktivni sadržaji neizostavni su dio suvremenih multimedijskih i interdisciplinarnih projekata te stoga autori i inicijatori takvih sadržaja u Hrvatskoj redovito u njih uključuju i Vjesnikovu Hemeroteku. Ovo se gradivo dotiče svih područja društvenoga života pa se može povezivati s gradivom druge provenijencije, nadopunjavati ga i ilustrirati, a ujedno i potaknuti korisnike da pretražuju i koriste i druge izvore.

\section{Zaključak}

Mediji, pa tako i novine, važni su ne samo za kulturu nego i za druga područja aktivnosti suvremenoga društva - od novinarstva, identiteta, komunikacije, slobode medija, medijske pismenosti i politika te za brojna druga pitanja. Razlozi zaštite toga dijela naci- 
onalne baštine, mogu se naći u riječima inicijatora projekta Muzeja medija da »medijski diskurs bilježi povijest na specifičan način, spašava od zaborava niz događaja, kao i medijske osobe koje su obilježile javni društveni život proteklih desetljeća... « ${ }^{12}$ Novinski tekst povjesničarima često predstavlja sekundarni izvor istraživanja, no Vjesnikova novinska i fotodokumentacija istraživačima povijesti 20. stoljeća u Hrvatskoj može pružiti korisno ishodište i širok okvir za njihov rad, koji će primjenom suvremenih tehnologija u njezinoj obradi i korištenju sve više dolaziti do izražaja.

\section{Literatura:}

»Hemeroteka«, u: Hrvatska enciklopedija, sv. $4(\mathrm{Fr}-\mathrm{Ht})$, Leksikografski zavod »Miroslav Krleža«, Zagreb, 2002., str. 515. URL: http://www.enciklopedija.hr/natuknica.aspx?id=24926 (pristupljeno 20. ožujka 2018.).

Ivica GRČAR, »Vjesnik daruje novinsku dokumentaciju Državnom arhivu«, Lider (6. veljače 2006.). Dostupno na: https://lider.media/arhiva/1297/ (pristupljeno 20. ožujka 2018.).

Željko HODONJ - Lana ŽAJA, »Mediji i demokracija, baza podataka, dubinsko pretraživanje, izravni pristup - digitalizacija novinskog arhiva i organizacija znanja u bazu podataka«, u: Sanja SELJAN - Hrvoje STANČIĆ (ur.), INFuture2007 Digital Information and Heritage. Odsjek za informacijske znanosti, Filozofski fakultet, Zagreb, 2007., str. 227-242.

Adrijana PITEŠA, »Kronologija slučaja: Vjesnikova arhiva. Kako je stvarana i zamalo uništena grandiozna zbirka novinskih članaka i fotografija«, Jutarnji list (8. lipnja 2013.) Dostupno na: https://www.jutarnji.hr/vijesti/vjesnikova-arhiva-kako-je-stvarana-i-zamalo-unistenagrandiozna-zbirka-novinskih-clanaka-i-fotografija/1151672/ (pristupljeno 20. ožujka 2018.).

Ivica GRČAR, »Otvorite i “novinarski arhiv" (bivšu VND)«, Autograf.hr (4. travnja 2017.). Dostupno na: http://www.autograf.hr/otvorite-i-novinarski-arhiv-bivsu-vnd/ (pristupljeno 25. ožujka 2018.).

Saša PAPARELLA, »Vjesnik novina koja je nestajala«, HND (14. travnja 2017.). Dostupno na: http://www.hnd.hr/vjesnik-novina-koja-je-nestajala (pristupljeno 5. travnja 2018.).

»Muzej medija interaktivnim pristupom spašava baštinu«, Poslovni dnevnik (10. ožujka 2018.). Dostupno na: http://www.poslovni.hr/hrvatska/muzej-medija-interaktivnim-pristupomspasava-bastinu-338554 (pristupljeno 5. travnja 2018.).

\section{Izvori:}

Vjesnikova novinska dokumentacija 1964-2006, Popis. Zagreb. Hrvatski državni arhiv, 2013.

HR-HDA-2031-2-1 Vjesnik. Vjesnikova novinska dokumentacija. Unutarnja politika. Hrvatska, reg. UP 26.

HR-HDA-2031-2-1 Vjesnik. Vjesnikova novinska dokumentacija. Unutarnja politika. Županije, reg. UP 167.

HR-HDA-2031-2-1 Vjesnik. Vjesnikova novinska dokumentacija. Unutarnja politika. Istra, reg. UP 168.

12 »Muzej medija interaktivnim pristupom spašava baštinu«, Poslovni dnevnik (10. ožujka 2018.). Dostupno na: http://www.poslovni.hr/hrvatska/muzej-medija-interaktivnim-pristupom-spasava-bastinu-338554. 
HR-HDA-2031-2-1 Vjesnik. Vjesnikova novinska dokumentacija. Unutarnja politika. Rat u Hrvatskoj, reg. UP 236.

Rješenje o utvrđivanju svojstva kulturnog dobra od 22. travnja 2013. (KLASA: UP/I-612-06/1327/03, URBROJ: 565-08/3-13-1).

\section{SAŽETAK}

\section{Vjesnikova novinska dokumentacija u Hrvatskom državnom arhivu kao izvor za povijest Istre}

Hemeroteke koje brojne ustanove vode sa svrhom dokumentiranja svojih aktivnosti predstavljaju značajan dokumentacijski izvor za povijesni pregled djelovanja i rada pojedine institucije, a često i cijeloga područja neke djelatnosti, društvenih zbivanja i povijesnoga konteksta svojega nastanka. Vjesnikova novinska dokumentacija, kao jedinstvena zbirka novinskih isječaka iz tiskovina koje su izlazile na području Jugoslavije i Hrvatske u razdoblju od pedesetak godina, svjedoči i o povijesti novinarstva i o životu u Hrvatskoj i susjednim zemljama u drugoj polovici dvadesetoga stoljeća.

Vjesnikova Hemeroteka, kao jedna od serija fonda Vjesnik, čuva se u Hrvatskom državnom arhivu od 2013. godine i sadrži oko $580 \mathrm{~d} / \mathrm{m}$ gradiva - isječaka članaka iz novina, tjednika i časopisa objavljivanih u tiskovinama iz Jugoslavije i Hrvatske u razdoblju 1962. - 2006. Ova je zbirka od svoga nastanka značajan informacijski izvor novinarima, medijskoj industriji i brojnim stručnjacima i znanstvenicima te je stoga u proteklih petnaestak godina bilo više pokušaja digitalizacije ovoga gradiva, što se nastavilo i u Arhivu. U radu se na primjeru Istre opisuju mogućnosti istraživanja ove Hemeroteke i načini njezina korištenja, detaljnije u okviru tematske cjeline Unutarnja politika. Kako je znatan dio ove dokumentacije u svezi s lokalnim temama, osobama i značajnim događajima iz javnoga života, vidljiva je njena korisnost za raznovrsna tematska istraživanja kao nadopuna, poveznica i ilustracija drugim izvorima.

\section{SUMMARY \\ Vjesnik Newspaper Documentation kept by the Croatian State Archives as a source for the history of Istria}

Newspaper and periodicals libraries kept by numerous institutions for the purpose of documenting their activities represent a significant source of documentation for a historical overview of the activities and work of an institution, and often of the whole area of an activity, social events and the historical context of its creation. The Vjesnik Newspaper Documentation, as a unique collection of press clippings from daily publications and other periodicals published in Yugoslavia and Croatia for over fifty years, is a witness of the history of journalism and life in Croatia and neighbouring countries in the second half of the twentieth century. 
Vjesnik's Hemeroteka - the Newspaper and Periodicals Library, as one of the series in the Vjesnik Fonds, has been kept by the Croatian State Archives since 2013 and contains about 580 linear meters of material - press clippings from daily and weekly publications and magazines published in Yugoslavia and Croatia in the period between 1962 and 2006. This collection has been an important source of information for journalists, the media industry and many experts and scholars ever since its emergence. For this reason, over the past fifteen years, there have been several attempts to digitize this material, which has continued in the Archives. On the example of Istria, the paper explores the possibilities of research of the Hemeroteka and the ways it can be used, more specifically within the topical unit of Domestic Affairs. As a significant part of this documentation is related to local topics, people and significant public life events, it appears useful for various thematic researches as a complement, link and illustration to other sources.

\section{RIASSUNTO}

\section{La documentazione giornalistica del Vjesnik nell'Archivio di Stato croato come fonte per la storia dell'Istria}

Le emeroteche, che vengono tenute da numerose istituzioni con lo scopo di documentare le proprie attività, rappresentano una fonte di documentazione importante per l'analisi dal punto di vista storico delle attività e dell'esercizio di una determinata istituzione, e spesso dell'intero settore di un'attività, delle vicende sociali e del contesto storico in cui sono nate. Inoltre, la documentazione giornalistica del Vjesnik, come raccolta unica di articoli dei giornali pubblicati nel territorio della Jugoslavia e Croazia nel periodo di una cinquantina d'anni, testimonia la storia del giornalismo e la vita in Croazia e nei Paesi vicini nella seconda metà del Novecento.

L'Emeroteca del Vjesnik, come una delle serie del fondo Vjesnik, è conservata nell'Archivio di Stato croato dal 2013 e contiene circa 580 metri lineari del materiale - inserti di articoli dei giornali, settimanali e riviste pubblicati sugli stampati della Jugoslavia e della Croazia nel periodo tra il 1962 e il 2006. Questa raccolta, dai suoi inizi, rappresenta una fonte informativa importante per i giornalisti, per l'industria mediatica e per innumerevoli professionisti e scienziati ed è per questo motivo che nell'ultima quindicina d'anni ci sono stati diversi tentativi mirati alla digitalizzazione di questo materiale, con cui hanno proseguito anche nell'Archivio. Nel testo vengono descritte, sull'esempio dell'Istria, le possibilità di esaminare tale Emeroteca e le modalità del suo utilizzo, nello specifico, nell'ambito dell'unità tematica Politica interna. Dato che una parte significativa di questa documentazione è relativa ai temi locali, alle persone e vicende importanti della vita pubblica, risulta evidente la sua utilità per le varie ricerche tematiche come supplemento, punto di riferimento e illustrazione alle altre fonti. 